\title{
Plagiarism checking - a new tool towards better science
}

\author{
Alcimar B Soares, $\mathrm{PhD}$ \\ Editor-in-Chief
}

\section{Dear readers}

As of August 2015, all manuscripts submitted to RBE are screened for plagiarism. We are now part of CrossCheck, a plagiarism checking service provided by CrossRef and powered by iThenticate software. All papers, as soon as they are submitted, are checked against "over 56 billion web pages and 142 million content items, including 44 million works from 590 scholary publisher participants ...", as declared by iThenticate (2015). This is part of our ongoing efforts to ensure publication of the highest quality papers.

As you all know, plagiarism has been the subject of great debate over the past years (Nature, 2012; Roig, 2010; Roig, 2015). Anyone involved with science has heard about at least one major scandal related to the "wrongful appropriation of somebody else's work". But the reality we face may go far beyond this basic concept.

The Merriam-Webster Online Dictionary defines plagiarism as "the act of using another person's words or ideas without giving credit to that person; the act of plagiarizing something" (Merriam-Webster Incorporated, 2015). This is the universally accepted definition of this term, which leads us to a very emphatic conclusion: "plagiarism is equal to theft". Hence, it goes without saying that we should always avoid using somebody else's words or ideas without proper citation.

But, how about copying your own work?

Many authors may think that, since it is their own work, they could use it in any way they like. To help us on that issue, let's check once again the Merriam-Webster Online Dictionary for the meaning of "to plagiarize": "to steal and pass off (the ideas or words of another) as one's own - use (another's production) without crediting the source"; "to commit literary theft - present as new and original an idea or product derived from an existing source" (Merriam-Webster Incorporated, 2015). Look at the last definition. It implies that we are committing plagiarism when we say that information already published is new, regardless the authorship. In other words, when we present an idea or work that we already published, we are committing what is known as "self-plagiarism". Add to this, the fact that when we submit an article to a journal we also that it has never been published elsewhere. Therefore, in so doing you may be providing a false statement and this can be seen as cheating by presenting your old idea as new (Spinak, 2013).

For some, it may sound like a very harsh measure to screen every paper submitted to RBE. But we trust that this is a very important measure, since we are, in fact, helping to protect authorship and the very foundation of good science.

\section{References}

iThenticate. About iThenticate Plagiarism Detection Software [internet]. 2015. [cited 2015 Aug 20]. Available from: http://www.ithenticate.com/about.

Merriam-Webster Incorporated. Marriam-Webster Online Dictionary [internet]. 2015. [cited 2015 Aug 20]. Available from: http://www.merriam-webster.com/dictionary/plagiarizing.

Nature. Science publishing: how to stop plagiarism. Nature. 2012; 481(7379):21-3. http://dx.doi.org/10.1038/481021a. PMid:22222735.

Roig M. Plagiarism and self-plagiarism: what every author should know. Biochemia Medica. 2010; 20(3):295-300. http:// dx.doi.org/10.11613/BM.2010.037.

Roig M. Avoiding plagiarism, self-plagiarism, and other questionable writing practices: a guide to ethical writing [internet]. 2015. [cited 2015 Aug 20]. Available from: http://www.cse.msu.edu/ alexliu/plagiarism.pdf.

Spinak E. SciELO en Perspectiva: etica editorial y el problema del autoplagio [internet]. 2013. [cited 2015 Aug 20 ]. Available from: http://blog.scielo.org/es/2013/11/11/etica-editorial-y-el-problema-del-autoplagio/. 